\title{
PitÁgorAS COMO ADIVINO: RELIGIÓN Y política en la Magna Grecia
}

\author{
David Hernández de la Fuente \\ Universidad Nacional de Educación a Distancia
}

Resumen: Entre todas las facetas del filósofo griego Pitágoras de Samos, algunas de ellas aparentemente contradictorias, hay un cierto número de fuentes antiguas que lo acreditan como una gran autoridad en artes proféticas. Las actividades políticas y la influencia de su escuela en la Magna Grecia fueron también a menudo destacadas en muchos aspectos. En esta contribución nos proponemos abordar la figura de Pitágoras como adivino en la Magna Grecia preguntándonos por la posible relación entre estos dos aspectos del sabio. Por un lado, discutiremos una serie de ejemplos del poder profético de Pitágoras, analizando la evidencia literaria e iconográfica. Por otro lado, repasaremos las posibles implicaciones políticas de estos episodios. Si nuestra hipótesis se confirma, se podría abrir la vía para señalar cierta relación entre el arte profético tradicionalmente atribuido a Pitágoras y su supuesta influencia política, de acuerdo con un patrón de liderazgo religioso y político documentado en otros casos de la historia griega antigua.

Palabras clave: filosofía antigua, Pitagorismo, religión griega, adivinación, política griega.

AbStRaCt: Amongst all the facets of the Greek philosopher Pythagoras of Samos, some of them seemingly contradictory, a certain number of ancient sources credited him with great authority on prophetic arts. The political activities and influence of his School in Magna Graecia were also often highlighted in many ways. In this contribution we intend to address the figure of Pythagoras as a soothsayer in Magna Graecia, in order to research the possible relation between these two aspects of his activity. On the one hand we will discuss a number of examples of 
Pythagoras' prophetic power, analyzing the literary and iconographic evidence. On the other hand, we will examine the possible political implications of such function. If our hypothesis is confirmed, we could open a research line on the interdependencies between the prophetic art traditionally ascribed to Pythagoras and his assumed political influence, according to a pattern of religious and political leadership attested in Ancient Greek history.

Keywords: Ancient Philosophy, Pythagoreanism, Greek Religion, Divination, Greek Politics.

cumque huic rei [scil. vera divinatione] magnam auctoritatem Pythagoras iam ante tribuisset, qui etiam ipse augur vellet esse.

Cicerón, De Divinatione i 346

Según las fuentes antiguas, el filósofo, político y chamán griego Pitágoras de Samos pasó por una gran autoridad en las artes proféticas. Si nuestra hipótesis de partida se confirma, esta facultad religiosa pudo servir como base de su autoridad sapiencial y política. En las páginas que siguen nos proponemos aducir una serie de ejemplos de la actividad mántica de Pitágoras, bien lejana a su tradicional consideración como padre de las matemáticas, que se encuentran en las fuentes literarias y en la iconografía y que parecen reforzar la idea de Pitágoras como un mediador profético con el mundo de lo divino. Curiosamente es esta misma prerrogativa religiosa la que parece conferirle una autoridad carismática en el liderazgo político que, según se constata en las fuentes históricas, ejerció este sabio en la Magna Grecia. Por un lado, así, se pasará revista en este artículo a los testimonios sobre la actividad mántica de Pitágoras en las fuentes literarias y, notablemente, en las tres grandes biografías tardías del filósofo, la Vida de Pitágoras de Porfirio de Tiro, el Sobre la vida pitagórica de Jámblico de Calcis y el libro dedicado a Pitágoras en las Vidas de filósofos ilustres de Diógenes Laercio. Por otro lado, se pondrán de relieve las facetas políticas de la secta pitagórica en los testimonios históricos. Nuestro propósito es destacar los aspectos coincidentes entre el arte profética tradicionalmente atribuida a Pitágoras y su supuesta influencia política siguiendo un viejo modelo de liderazgo entre religión y política que se puede constatar en las fuentes sobre la historia arcaica de Grecia.

\section{Mántica Pitagórica}

Veamos, en primer lugar, los testimonios sobre el aprendizaje religioso del sabio de Samos en Oriente que, además de reflejar un tópico de la educación 
de los filósofos griegos, abunda especialmente en la mántica. Porfirio, por ejemplo, refiere que el sabio de Samos aprendió en diversos países fuera del mundo griego los saberes religiosos que luego llevó a Grecia: en Egipto, Babilonia y Tracia, por ejemplo. Allí, dice el biógrafo, había aprendido las doctrinas del alma y de los números. En su visita a Siria y antes de partir hacia Egipto, Jámblico hace descender a Pitágoras nada menos que del monte Carmelo, la montaña «más sagrada de todas» (Porfirio, Vit. Pyth. 14), célebre por haber sido el lugar profético de Elías en el Antiguo Testamento y la sede de la secta de los esenios. ${ }^{1}$ Pero, más allá de sus precedentes orientales, las biografías centran su aprendizaje de la mántica precisamente en su paso por Creta. En la isla de Minos, Pitágoras es iniciado en los misterios de Zeus y de los Dáctilos - protoi heuretai de la metalurgia y la hechicería subterránea

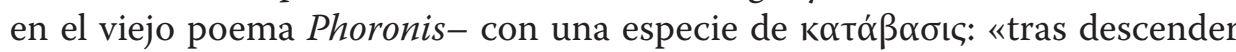
a la llamada cueva del Ida en aquellos ropajes de negra lana permanecía allí tres veces nueve días rindiendo tributo a Zeus». ${ }^{2}$ Del mismo modo pasa un tiempo Minos, cada nueve años, en la misma cueva del Ida o Hefesto, según el mito, se oculta en la cueva durante otros nueve años: es esta una suerte de periodo de simbólica gestación - de ahí el número nueve- para obrar la vuelta a la vida después de la muerte ritual. De una manera ritualizada también, con una vestimenta especial y tras ser iniciado en los misterios del Ida, Pitágoras habría descendido a la misma cueva donde había tenido lugar la incubación de Minos. El detalle de la lana negra parece entrar en contradicción con el lino blanco que normalmente se vestía en las purificaciones, tanto en los misterios como en las consultas oraculares y que luego heredaría el mundo pitagórico. ${ }^{3}$ Porfirio (Vit. Pyth.17) añade que en esa gruta Pitágoras pudo ver «el trono que se prepara cada año para el dios» y la llamada «tumba de Zeus» donde, según la tradición religiosa cretense, ${ }^{4}$ yacía el cuerpo del dios, grabando una inscripción con la dedicatoria «De Pitágoras a Zeus» que decía: «aquí yace muerto Zan, a quien llaman Zeus». Las creencias de los misterios cretenses de Zeus incluían la idea de que Zeus había muerto allí, donde se veneraba su tumba. Parece que Pitágoras adaptó esta práctica también al regreso de Creta, en su Samos natal: «hizo suya una gruta que había en las afueras de la ciudad para la práctica de su filosofía. En su interior pasaba gran parte del día y de la noche junto con unos pocos compañeros». ${ }^{5}$

Es significativo que la enseñanza de la filosofía de Pitágoras, en su primera escuela en Samos, llamada el «Semicírculo», se sirva de los patrones de aprendizaje iniciático del descenso a la caverna que el biógrafo Jámblico (Vit. Pyth. 27) compara con la experiencia de «Minos, el hijo de Zeus». El uso de la cueva, tanto en Samos como posteriormente en Crotona, acerca el pitagorismo

1. Libro de los Reyes, I, 18, 19-40 y II, 2, 25. Sobre los esenios, Josefo: Bell. Jud. II, 119, 158, 160.

2. Porfirio: Vit. Pyth., 17.

3. JÁmblico: Vit. Pyth. ,xxi, 100

4. Cf. sobre los misterios cretenses Diodoro de SiCilia: III, 61; CiCERón: De natura deorum, III, 21, 53.

5. Porfirio: Vit. Pyth., 9. 
al mundo de la mántica subterránea, reproduciendo el patrón del chamán que viaja al más allá a través de la incubación en la gruta para conocer allí el futuro: este comportamiento admite también una interesante comparación con los ascetas y ermitaños cristianos. ${ }^{6}$

Por su parte, Diógenes Laercio resume los viajes y el aprendizaje místico de Pitágoras en la cueva de la siguiente forma (viII 3):

Estuvo, pues, en Egipto, ya que Polícrates le recomendó mediante cartas a Amasis [...]. También pasó un tiempo entre los magos caldeos. Y luego en Creta descendió con Epiménides a la cueva del Ida. Pero también penetró en los sanctasanctórum de Egipto, quedando versado en los asuntos divinos por medio de secretos saberes. En seguida regresó a Samos y allí encontró su patria bajo la tiranía de Polícrates, por lo que partió a Crotona, en Italia.

Allí, otros testimonios apuntan también que Pitágoras hizo uso de una cueva, tras su emigración a la Magna Grecia, con un propósito relacionado con sus enseñanzas sobre el alma y la mántica: hay un testimonio escéptico de Hermipo que refiere también Diógenes, ${ }^{7}$ y que pretendía desvelar el fraude que tramó Pitágoras en Crotona para fingir una revelación profética:

[...] se hizo una morada subterránea y le encomendó a su madre que escribiera las cosas que ocurrieran en una tablilla, y señalando también el momento en que ocurrían, y que luego se la enviase allá abajo hasta que subiera de nuevo [...]. Luego Pitágoras regresó después de un tiempo delgado y casi convertido en un esqueleto y tras presentarse ante la asamblea proclamó que había llegado del Hades. Y entonces les leyó las cosas que habían sucedido.

Aunque se transmite la noticia de forma crítica, para desenmascarar la falsa profecía, esta información transfiere la figura de Pitágoras al mismo modelo de los personajes antes mencionados, con su proceso ascético de sufrimiento en la katábasis de la gruta para alcanzar el conocimiento secreto. Cabe aquí recordar también la historia paralela del fraude atribuido al chamán tracio Zalmoxis. ${ }^{8}$

Hay una serie de thaumata en los autores antiguos que relacionan a Pitágoras con los actos de chamanes como Epiménides, Aristeas, Hermotimo o Abaris, pero también con démones proféticos como Trofonio o Anfiarao. ${ }^{9}$ Pitágoras aparece como un dios encarnado entre los hombres, o una criatura de mediación, ni humana ni divina, como reza el conocido enigma sobre Pitágoras «Bípedo son el hombre, el ave y otro tercer ser»..$^{10}$ Además de los thaumata y las profecías, el célebre muslo de oro, que se comentará en breve,

6. Cf. LÉvy: 1927, Gorman: 1979 [1988], 81 y 87, Bremmer: 1992.

7. Dióg. LAERCiO: VIII, 41.

8. Herodoto: V, 94-96.

9. Apolonio: Mir., 6.

10. Jámblico: Vit. Pyth., 144. Cf. Delatte: 1915, 16 y Riedweg: 2002 [2005], 34. 
es la evidencia física de su naturaleza sobrehumana. El carácter mediador de Pitágoras queda así señalado como un don, un privilegio pero también un riesgo y una fuente de dudas y preguntas, definido por sus reencarnaciones y su memoria de ellas y, sobre todo, por la frecuente salida del alma de su cuerpo en bilocaciones, incubaciones y milagros variados de presciencia y sabiduría divina: la capacidad de adivinar el futuro es solo el punto culminante de estos poderes mágicos del filósofo.

Por un lado, la forma en la que Pitágoras obtiene el arte de la aritmética se relaciona con el mundo de la mántica: se cuenta que Orfeo le enseñó la manera de conocer a la divinidad mediante el número (Jámblico Vit. Pyth.,145-147) cuando el chamán tracio le reveló que «la esencia eterna del número es el principio que mejor permite acceder al aprendizaje prognóstico». Pitágoras, sigue diciendo Jámblico, «alcanzó una admirable presciencia a través de los mismos números [...] de donde se hace evidente que la esencia de los dioses determinada por el número la tomó de los órficos». Llegó a instruir al chamán Abaris este nuevo tipo de adivinación por numeromancia:

[...] puesto que Abaris continuaba sus actividades divinas, según era su costumbre, y practicaba la adivinación por sacrificios, que es la más estudiada en todas las razas de los bárbaros, especialmente la que se dedica a los pájaros (pues considera que en las entrañas de estos son certeras para los vaticinios), Pitágoras, que no deseaba erradicar de él esta práctica de la verdad pero sí proporcionarle un medio más seguro y que no implicaba matanza ni derramamiento de sangre - pues por otra parte consideraba consagrado el gallo al sol- le procuró al fin la llamada «verdad absoluta», ordenada por la ciencia aritmética.

En segundo lugar, la manera en que Pitágoras descubre la armonía y la música se relata en una historia legendaria con ribetes de inspiración mántica. Se dice que Pitágoras obtuvo una especie de azar o intuición divina (theia tyche) al pasar por una fragua. Allí, al escuchar los golpes del martillo sobre el yunque, descubrió de forma inspirada las proporciones numéricas que rigen las escalas musicales y a partir de ahí fue deduciendo cada tonalidad básica, como cuentan las fuentes antiguas, y descubriendo diversos instrumentos musicales. ${ }^{11}$ Aquí llama especialmente la atención la imagen de la fragua, volcánica gruta de Hefesto, como momento de la revelación divina relacionada con la mántica, del dios orfebre y herrero, cuya morada subterránea es un lugar especialmente consagrado para los viajes de ida y vuelta al más allá. ${ }^{12}$ También cabe recordar aquí las cofradías de artífices relacionadas con Hefesto y con el mundo de las fraguas en la religión griega -como los Curetes, Coribantes o Dáctilos- que sirven de maestros iniciáticos en grutas volcánicas. Por ello no está simbólicamente fuera de lugar aquí la mención de

11. JÁmblico: Vit. Pyth., 115.

12. EliADE: 1956 [1974]. 
la fragua en la inspiración de la que quizá es el descubrimiento más célebre de Pitágoras: la proporción numérica de la música y la armonía como reguladora del cosmos. Se trata, sin duda, de un elemento mágico y legendario, producto de la consideración del sabio como hombre divino y apto para una inspiración cercana a la profecía.

En la tradición literaria y mítica griega hay diversos momentos de revelación divina junto a las fraguas, y en referencia especial a algún héroe mítico, categoría que parece aquí ocupar el propio Pitágoras. En un par de leyendas sobre los descubrimientos de los huesos de héroes famosos, como Orestes o Teseo, se hace uso de semejante inspiración divina (theia tyche o theia moira). Refiere Heródoto el caso de los restos de Orestes llevados a Esparta en plena época de los tiranos, hacia el 550 a. C., ${ }^{13}$ siguiendo un oráculo que había revelado que Esparta solo vencería la guerra contra Tegea cuando los huesos de Orestes que al parecer se hallaban en la misma Tegea-fueran debidamente localizados y enterrados. El oráculo, como siempre ambiguo, indicaba con un enigma el lugar donde se encontraban los restos del héroe, «allí donde soplan dos vientos bajo una poderosa necesidad, donde golpe contra golpe hay sufrimiento sobre sufrimiento». El jefe espartano Licas, que había entrado en la ciudad durante una tregua, descubrió por inspiración divina que se refería a una forja, tras lo cual recuperó los huesos de Orestes, y finalmente, Tegea fue derrotada. Cuenta Plutarco, por otro lado, que un oráculo había indicado a los atenienses la necesidad de recuperar los huesos de Teseo, enterrados en algún lugar de la isla de Esciros. ${ }^{14}$ El estratego Cimón, según Plutarco, descubrió los huesos mediante un prodigio inspirado "por algún divino azar» (theia tini tyche), al ver un águila que excavaba en un montículo, donde halló al fin los huesos del héroe. En el caso similar de Pitágoras su gran descubrimiento de la armonía fue propiciado por la variación de tonalidades de los martillos golpeando el yunque, con lo que luego relacionó el sonido con el peso en diversas proporciones. Esta leyenda entra en la categoría de los mitos, pues, como ha notado Burkert, entre otros autores, la relación directamente proporcional es falsa. ${ }^{15} \mathrm{La}$ escenografía de la fragua como lugar del descubrimiento, en fin, pone la historia en relación con otras revelaciones oraculares de este tipo.

En cuanto a la meditación, se efectuaba en dos momentos clave para la conexión del alma con el más allá: el acostarse y el despertar, pues los sueños eran tenidos como episodios mánticos por el maestro. ${ }^{16}$ La práctica de la meditación otorgaba una enorme cohesión espiritual al grupo pitagórico, así como una marca distintiva de su modelo ético: la manera ascética en la que el maestro puede sustraerse del mundo y dejar de alimentarse para entrar en trance meditativo, que según Jámblico aprende de Tales, sorprende a

13. I, 67-68. Cf. también Pausanias: III, 3, 5-6, Diodoro de Sicilia: IX, 36, 3.

14. Plutarco: Tes., 36; Cim., 8, 5-7.

15. BURKERT: 1962a [1972], 375.

16. Porfirio: Vit. Pyth., 40. 
los mortales comunes, como los mercaderes que le llevan en el barco hacia Egipto. ${ }^{17}$ También tomaba una especie de alimentación ritual para iniciar la meditación en los templos de una forma que recuerda a la comida mística antes de la incubación o sueño profético ritual: ${ }^{18}$

La mayor parte de las veces, cuando se disponía a sumirse en los sanctasanctórum de las divinidades y pasar allí una temporada, usaba solo alimentos para evitar morir de hambre o de sed. Para el hambre hacía una compota de semilla de adormidera y sésamo, corteza de una cebolla albarrana, tras limpiarla cuidadosamente hasta extraer su jugo, flor del narciso y hojas de malva, granos de cebada y garbanzos. De todo esto tomaba una medida igual de peso y tras trocear en pedazos pequeños, lo untaba con miel del Himeto. Para la sed, con semilla de pepino y sabrosas uvas pasas, tras sacar de ellas el grano, y con flor de cilantro, y también semillas de malva, verdolaga, queso troceado, harina y crema de leche. Todos estos ingredientes los mezclaba con miel silvestre.

Estas reglas de alimentación ascética, previas a la meditación incubatoria, sin duda se refieren también a la incubación en los adyta de la divinidad y al especial ayuno que requiere, sobre todo si se combina con los detalles ya comentados sobre el aprendizaje en las cuevas en Creta y las ropas especiales para el descenso. ${ }^{19}$ La comparación con el procedimiento del oráculo de Trofonio es muy significativa. En cuanto a la comida mística que ingiere Pitágoras, se parece al kykeon que se ingería en los misterios de Eleusis de Deméter, una suerte de «comida de poder» preparatoria para la experiencia mística. ${ }^{20}$

La conexión de Pitágoras con Apolo y la mántica es evidente no solo desde su nacimiento - pues su ancestro Anceo fundó Samos siguiendo un oráculo de Apolo y a su padre Mnesarco le profetizaron en Delfos la gloria de su hijo- ${ }^{21}$ sino también en otros detalles aparentemente menores de su biografía, como, por ejemplo, la elección de Euforbo como una de las vidas pasadas que siempre recordaba el maestro. El héroe homérico era en la Ilíada un aliado de Apolo en la muerte de Patroclo. ${ }^{22}$ También hay que recordar la relación de Pitágoras con Delos, la isla donde nace Apolo y uno de sus santuarios más importantes desde la época arcaica. ${ }^{23}$ Allí se supone que efectuó Pitágoras sus célebres sacrificios a Apolo Genitor de forma incruenta, mostrando su nueva forma de religiosidad; ${ }^{24}$ después, dice Jámblico: «se marchó desde allí a todos los oráculos». También en Delos cuidó a su moribundo maestro Ferécides y le dio

17. Jámblico: Vit. Pyth., 12-16

18. Porfirio: Vit. Pyth., 34-35.

19. Cf. KingSLeY: 1999 [trad. esp. 2010², 77-85], o DodDS: 2006 [1980], 138-148.

20. Gorman: 1979 [1988], 93-94. RiedWEG: 2002 [2005], 31.

21. JÁmblico: Vit. Pyth., 4-5.

22. RiEDWEG: 2002 [2005], 72-73.

23. Himn. Hom. Apolo, III.

24. Jámblico: Vit. Pyth., 25. Dióg. Laercio: vili, 13. 
sepultura en esta isla sagrada, de la cual se retiraron todos los cadáveres en señal de purificación en época de Pisístrato (c. 540 a. C.) y donde, posteriormente, Atenas decretó que de que nadie naciese o fuese enterrado (c. 426 a. C.). ${ }^{25} \mathrm{El}$ hecho de que Pitágoras realizara allí los ritos fúnebres de su maestro es, por tanto, un indicador muy significativo de su relación sapiencial con Apolo y de su identificación con su culto délico.

En Delfos, por otra parte, se dice que mandó grabar una inscripción anunciando la muerte de Apolo: ${ }^{26}$ "versos elegíacos en la tumba de Apolo, en los que evidenciaba que Apolo era hijo de Sileno, pero que fue muerto por Pitón y recibió honras fúnebres en la aldea llamada Trípode». Se trataba quizá de una lección aprendida en Creta, donde había sabido de la muerte del Zeus cretense en los misterios de los Dáctilos del Ida. No hay que pasar por alto el hecho de que existan abundantes testimonios de que Ferécides de Siro, más que un reputado filósofo o cosmólogo precursor, fue un hombre divino, un profeta y un chamán. ${ }^{27}$ Ferécides, maestro de Pitágoras, tenía poderes proféticos, que había usado también para la política, como legislador mántico de Esparta. ${ }^{28} \mathrm{La}$ enseñanza simbólica que ejercía Pitágoras en su escuela recuerda de cerca a la poesía enigmática de los oráculos de Apolo Loxias en hexámetros y, como esta, no admite una fácil interpretación, sino que es preciso un estudio detallado y una iniciación en los misterios de la secta, como recuerda Jámblico (Vit. Pyth., 247):

De forma particular y mediante símbolos se daba toda la educación pitagórica, parecida a enigmas y acertijos, por su carácter sentencioso y arcaico, de manera similar a los divinos vaticinios del dios de Delfos, que parecen en cierto modo difíciles de entender e interpretar para los que consultan el oráculo de forma poco seria.

El aprendizaje de Pitágoras está relacionado con el mundo délfico, pues en el santuario aprendió de la pitia Temistoclea o Aristoclea su manera de expresión. ${ }^{29}$ Hay una lista de algunos dicta que habría aprendido de la pitia y que enseñaba de modo místico y simbólico: «Por ejemplo, al mar lo llamaba "lágrima"; a las osas, "las manos de Rea"; a las Pléyades, "lira de las Musas"; a los Planetas, "los perros de Perséfone" y al sonido que se produce al entrechocar dos instrumentos de bronce, "la voz de un tipo de demonio que hay encerrado en el bronce"». ${ }^{30}$ La doctrina pitagórica era como el oráculo: difícil de entender pero que, una vez superados los enigmas que la envolvían, era capaz de proporcionar un conocimiento supremo:

25. Diodoro de Sicilia: X, 3-7, Porfirio: Vit. Pyth., 15, 55.

26. Porfirio: Vit. Pyth., 16.

27. SCHibli: 1990, 1-11.

28. TeOPOMPO: FGrHist, 115, F71

29. Porfirio: Vit. Pyth., 8, 21 y DióG. LAercio: VIII, 8 llaman a la pitia respectivamente Aristoclea y Temistoclea. Gorman: 1979 [1988], 92.

30. Porfirio: Vit. Pyth., 41. 
[...] si los dichos son desarrollados según la manera de ser de estos símbolos, aparecen a la vista claros y brillantes ante la mayoría, en vez de oscuros, y son comparables a las profecías y oráculos de Apolo pítico. Entonces revelan una intención admirable y producen una inspiración divina en los estudiosos que los han comprendido. ${ }^{31}$

En otro lugar se cuenta que él se tenía por un dios dador de oráculos, al ser increpado por los embajadores de Síbaris por su prepotencia: ${ }^{32}$ «uno le acusó de ir diciendo que era Apolo una vez que alguien le formuló en el pasado la pregunta de "por qué algo era así" y Pitágoras le replicó si también cuando Apolo pronunciaba oráculos él estimaba digno interrogarle sobre sus razones». El mismo Jámblico, que refiere esta anécdota, también compara los akousmata del maestro con oráculos de Delfos mientras que Porfirio dice que sus oyentes recibían su palabra como leyes divinas. ${ }^{33}$ En la enseñanza esotérica de Pitágoras, a la que solo los miembros más autorizados eran admitidos, estas y otras señales recuerdan a los cultos religiosos y sus grados -también los sacerdotes en Delfos estaban jerarquizados en hiereis, prophetai y hosioi-, y particularmente con el culto de Apolo. ${ }^{34}$

Aunque Pitágoras practicaba un tipo de adivinación técnica, por números, su figura encarna sobre todo otro tipo de presciencia inspirada y naturalemente relacionada con Apolo, ya sea a través de los sueños proféticos o de la revelación o posesión semejante a la de la Pitia délfica, por ciertos dioses o démones mánticos. Mediante su labor de mediador mántico, y usando la mediación de otros seres intermedios de una manera que recuerda a la teurgia neoplatónica, dicen las fuentes que era versado en todo tipo de oráculos y adivinaciones, como en este pasaje de Diógenes Laercio (vIII, 32):

[...] dicen que el aire está lleno de almas y que estas son las que se consideran démones y héroes. Y que por medio de ellas se envían los sueños a los seres humanos y las señales de enfermedad, y no solo a los hombres, sino también a las ovejas y a otros animales domésticos. Pues a través de ellos se producen las purificaciones y los sacrificios de alejamiento del mal, todos los tipos de adivinación, los oráculos de azar y las cosas de este estilo.

La propia identificación de Pitágoras con el Apolo Hiperbóreo tiene una impronta mántica muy relevante, que se ve en el conocido detalle del muslo de oro, que lo relaciona irremisiblemente con el mundo apolíneo. La leyenda acerca del muslo de oro de Pitágoras, que mostraba en contadas ocasiones, ha sido comparada con la de la sandalia de bronce que deja Empédocles antes de desaparecer en el Etna, ${ }^{35} \mathrm{o}$ también con los diversos rasgos sobrenaturales

31. Jámblico: Vit. Pyth., 105.

32. Jámblico: Vit. Pyth., 177. Cf. Gorman: 1979, [1988], 187.

33. JÁmblico: Vit. Pyth.,161 y Porfirio: Vit. Pyth., 20.

34. Eliano: VH it, 26, Dióg. Laercio: vili, 13; Jámblico: Vit. Pyth, 8, 91, 141.

35. Dióg. LAercio: Viiı, 69. Cf. KingSley: 1995 [2008], 382 y ss. para la comparación. 
que caracterizan a los chamanes, quizá como un tatuaje, a imagen de los escitas y tracios, o del cretense Epiménides y su piel tatuada con enigmas. ${ }^{36}$ Hay ciertos héroes griegos que tienen partes del cuerpo de materiales diversos: como Pélope, al que su padre sirvió en un impío banquete a los dioses. Estos le pusieron un hombro de marfil cuando el suyo fue devorado por la distraída Deméter. ${ }^{37}$ Pitágoras muestra su muslo de oro a Abaris, el mítico chamán hiperbóreo que viajaba sobre una flecha y era sacerdote del Apolo Hiperbóreo, el «dios de oro», como lo llama Jámblico (Vit. Pyth.91). El mítico país de los Hiperbóreos es mencionado por Herodoto (IV, 32-36), que menciona, entre otros poetas griegos que trataron el tema, al chamán Aristeas de Proconeso, que escribió sobre esa tierra del norte en su epopeya Arimaspea. Allí vivían razas legendarias como los Isedones o los Arimaspos, y los grifos del Apolo del norte guardaban el oro hiperbóreo. Entre las identificaciones del país septentrional destacan las tierras chamánicas del norte de Tracia y de Escitia. ${ }^{38}$ La asimilación de Pitágoras, y su muslo del oro, con el dios de oro venido del norte procede directamente del sacerdote hiperbóreo Abaris, quien no duda en identificar al sabio con el propio dios, asimilado con Apolo..$^{39}$ De hecho, una de las máximas pitagóricas que refiere Jámblico hablando del episodio del muslo de oro, era: «¿Quién eres, Pitágoras?: Apolo Hiperbóreo». ${ }^{40}$ La identificación de Pitágoras con el culto de Apolo salta a la vista en la iconografía antigua en una moneda de Crotona (de fecha desconocida) que contiene un retrato de un pensativo Pitágoras en un lado y otro de Apolo-Helios en el reverso, coronado como dios sol (Fig. 4).

Existen otros dichos pitagóricos que guardan también relación con el mundo de la mántica apolínea y de la poesía oracular. Una definición clave, de las que Jámblico recoge como medio de aprendizaje por medio de preguntas y respuestas es el enigma "¿Qué es el oráculo de Delfos? La tetraktys». ${ }^{41}$ La tetraktys se refería al conjunto de los cuatro primeros números, que se esquematizaban en un triángulo compuesto por líneas de uno a cuatro puntos. La suma de estos, diez, era considerado como el número perfecto en el Pitagorismo de la época de Filolao. Vemos aquí cómo la supuesta doctrina central de la matemática pitagórica, el concepto de tetraktys, queda identificada muy significativamente con el culto de Apolo. La comparación con el oráculo de Delfos, centro cultural y religioso del mundo griego y sede de la sapiencia mántica tradicional, equivale a decir que en la tetraktys estaba encerrado el enigma de Apolo y todo su saber profético. Se trataba de un concepto central en el Pitagorismo, pues en el juramento que se atribuye a los miembros de la

36. Meuli: 1935, 161 s., Dióg. Laercio: i, 114 s. Sobre el muslo de oro como tatuaje, Gorman: 1979 [1988], 127. En general, cf. HeRnÁndeZ de LA Fuente: 2012.

37. Para el mito, cf. Licofrón: Alex., 149 ss., Higino: Fab., 83, Ovidio: Met., vi, 405 ss.

38. Allí sitúan a Bóreas Sófocles: Ant., 980, Esquilo: Ag., 193, entre otros, mientras que Aristóteles: Met., 1. 13. 350b, localiza la región al norte de Escitia.

39. Porfirio: Vit. Pyth., 28. Cf. también Dióg. Laercio: viir, 11.

40. JÁmblico: Vit. Pyth., 135 y 140.

41. JÁmblico: Vit. Pyth., 81-82. 
secta en la tradición posterior - por ejemplo, en los tardíos Versos de Oro- se jura por «aquel que dictó la tetraktys a nuestra estirpe».

Es un saber tan enigmático como las máximas grabadas en el templo de Apolo Loxias en Delfos y el trípode apolíneo que, no en vano, fue mandado grabar en las monedas de la ciudad de Crotona (Fig. 1). La leyenda de la fundación peloponesia, en torno a 733 a. C., de Crotona, ciudad elegida por Pitágoras para establecer su culto, se debía a un oráculo del propio dios Apolo, como sucede a menudo con otras colonias griegas. ${ }^{42} \mathrm{~A}$ ese respecto, es muy notable ver la relación en ciertas acuñaciones de monedas del mundo griego de Pitágoras y de Apolo, el dios de la adivinación (Figs. 2-4). En todo caso, diversos indicios hacen de Crotona una sede importante del culto de Apolo en la que Pitágoras es recibido como un hombre divino «cuyas enseñanzas orales se tenían por oráculos divinos» (Dióg. Laercio viII 14) y que «dedicaba especial atención a los vaticinios, profecías y augurios y, en suma, a todo tipo de cosas que surgían espontáneamente» (Jámblico Vit. Pyth.,149).
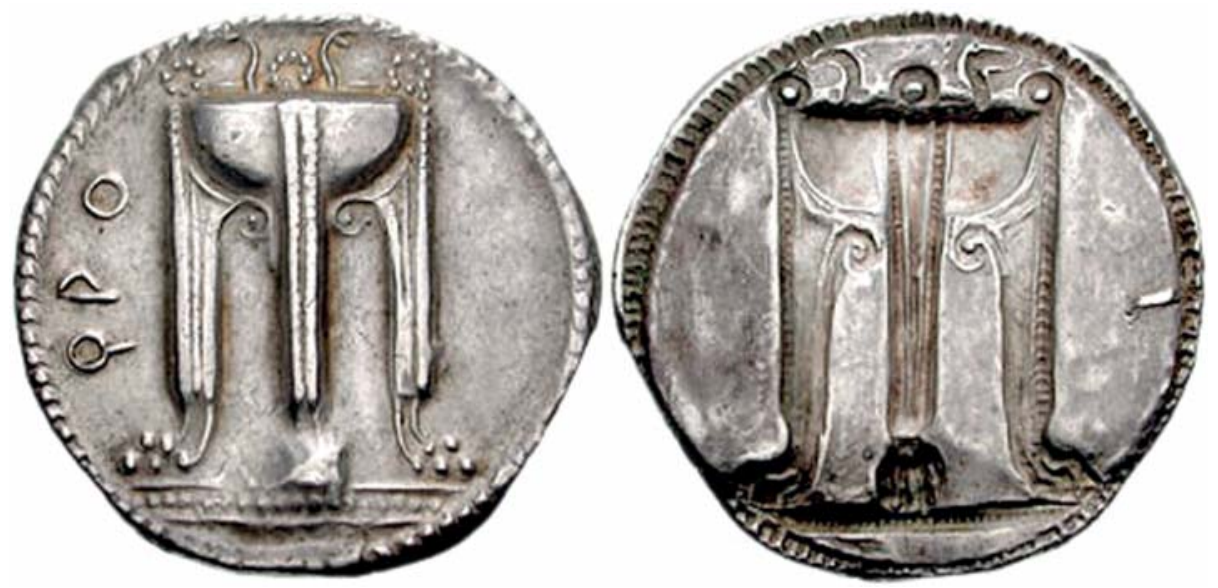

Fig. 1. Moneda de Crotona con el trípode de Apolo (530-520 a. C.)
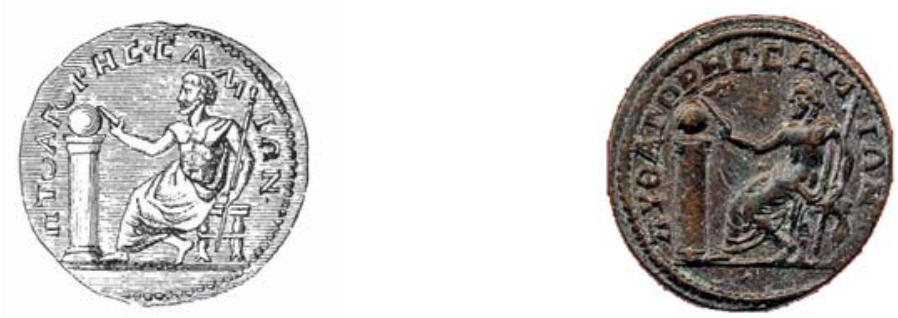

Fig. 2. Moneda de Samos (s. II) con Pitágoras 


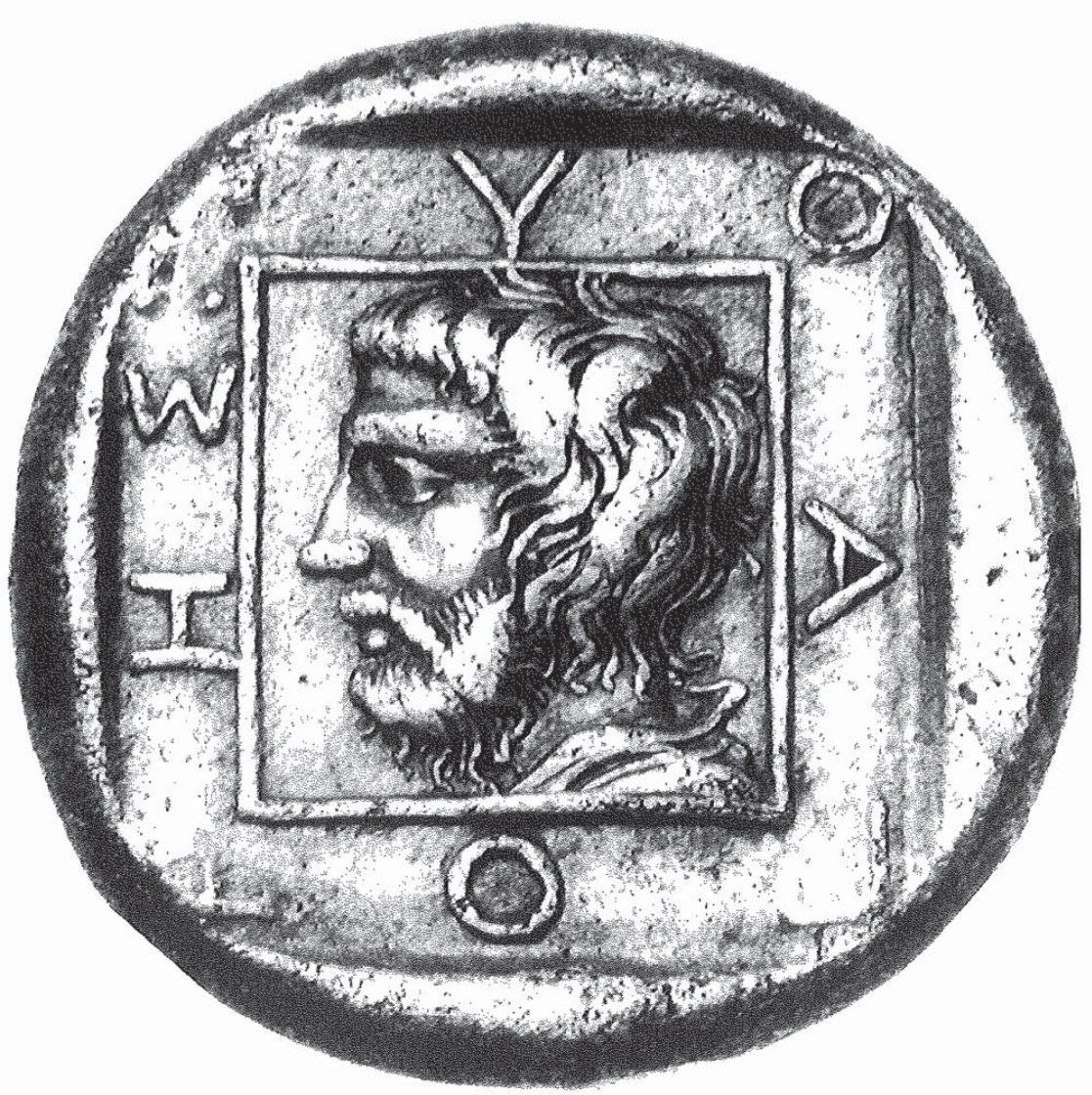

Fig. 3. Moneda de Abdera (430-425 a. C.) con retrato de Pitágoras. Museo Gulbenkian, Lisboa
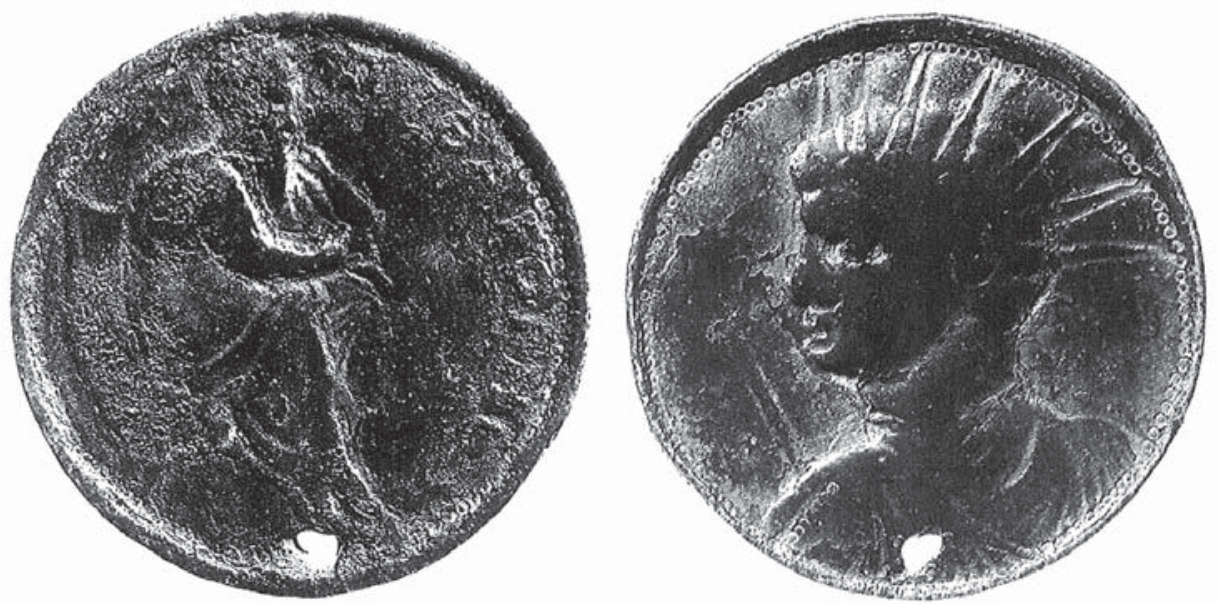

Fig. 4. Moneda de Crotona (fecha desconocida) con retrato de Pitágoras (verso) y ApoloHelios (recto) 


\section{Política Pitagórica}

La segunda vertiente de Pitágoras que queremos destacar en esta contribución es su faceta política, que se combina de manera muy singular con su actividad como adivino. El filósofo de Samos se convirtió, poco después de su llegada a Crotona, en un líder carismático, en el sentido weberiano, de una secta religiosa que también tuvo una influencia determinante sobre la sociedad externa y, notablemente, en la política de su época. Con ello, a nuestro ver, Pitágoras sigue un antiguo arquetipo de la historia de las religiones que ya aparece en el mundo griego desde Homero. No en vano, en la Ilíada, los sacerdotes de Apolo, Calcante o Crises, resultan fundamentales como personajes de gran prestigio y respetados por toda la comunidad política. ${ }^{43}$ Lo que conocemos de la Grecia arcaica, y de sus antecedentes, es señal de un punto de convergencia entre el basileus o líder político de la comunidad, y el mantis o adivino: la palabra del rey es a menudo interpretada como ley sagrada y semejante a un oráculo. ${ }^{44}$ Sobre esta simbiosis entre adivinación y legislación en la Grecia arcaica hay diversos testimonios: en Trecén, en época romana, Pausanias vio una tumba en honor del rey Piteo, donde se le tributaba culto heroico. Piteo aparecía representado como juez -la palabra regia como ley- pero también como chresmologos o adivino -la palabra regia como oráculo. ${ }^{45}$ Por otro lado, en Tebas y Esparta los reyes guardaban celosamente sus colecciones de oráculos y es conocido el caso de la falsificación de oráculos en la Atenas de la tiranía pisistrátida en el siglo vi a. C. ${ }^{46}$ Parece que a partir de comienzos del siglo v a. C. esta convivencia entre lo político y lo mántico se atenúa ligeramente, aunque la consulta oracular con fines públicos no dejará de tener relevancia a lo largo de todo el siglo, como acredita el beneficio de la promanteia o prioridad en los oráculos para autoridades políticas. Otro resto de esta antigua amalgama entre mántica y política será la mediación oracular y sacerdotal a lo largo de los dos grandes conflictos bélicos del siglo, la guerra contra los persas y la guerra del Peloponeso, en los que Delfos será un lugar de decisión política panhelénico y a merced de las potencias hegemónicas de cada época. ${ }^{47}$

En este sentido, y según nuestra hipótesis de trabajo, Pitágoras representa el más claro ejemplo de adivino con influencia determinante en la política en el mundo griego: un «consejero político» que tiene a la vez un contacto privilegiado con lo divino. ${ }^{48} \mathrm{Es}$, pues, necesario un enfoque temático en el análisis de las fuentes sobre el Pitagorismo que dé cuenta de esta excepcionalidad del mediador divino en la esfera pública, y de la influencia

43. HOM.: Od., XVII, 382.

44. Detienne: 1967 [2004], 92-93.

45. Pausanias: il, 313.

46. PAUSANIAS: III 31 5; IX 263.

47. Cf. Hernández de la Fuente: 2008, 148-177.

48. Delatte: 1922, Von Fritz: 1940 o Minar: 1943. Cf. recientemente Hidalgo de la Vega: 2001 y RIEDWEG: 2002 [2005], 60 ss. 
determinante de estas ideas sobre el pensamiento posterior. Los fundamentos políticos del Pitagorismo saltan a la vista no solo en las fuentes que hablan de la vida de Pitágoras, sino también en los historiadores de la Magna Grecia. El mismo Pitágoras a menudo representa la figura del legislador inspirado, como se desprende de su aparición en el Busiris de Isócrates, aprendiendo la constitución divina de Egipto. Este país, como modelo político y social, aparece ya desde antiguo en la literatura griega, desde el estudio de su sistema de castas en Heródoto hasta Isócrates, ${ }^{49}$ pues Egipto fue modélico para los griegos en muchas cosas y también en cuanto a las leyes perfectas. ${ }^{50}$

Estos viajes de aprendizaje del legislador mítico a un lugar utópico y lejano donde aún reina la «buena y antigua ley», y sobre todo a Egipto, son un rasgo que hay que señalar y que está presente en algunos filósofos presocráticos cuya faceta legisladora comparte espacio conceptual con la mántica. Ocurre, en concreto, en el ámbito de la Magna Grecia y con personajes que es imposible disociar de la figura del legislador sagrado, hombre divino y mediador, como son Minos y Licurgo. Ambos legisladores míticos de Creta y Esparta, que eran ciudades modélicas del mundo dorio por sus excelentes constituciones emanadas de la divinidad, están inspirados desde el mundo de la mántica -el uno por la incubación en la cueva del Ida, el otro por el oráculo délfico-.$^{51}$ Minos legisla en Creta tras recibir las leyes de Zeus y Licurgo es el héroe responsable de las leyes de Esparta (la Rhetra), que aprendió primero en Creta ${ }^{52}$ y Egipto, ${ }^{53}$ y luego fueron refrendadas por Apolo en Delfos, que le concedió directamente «la mejor ley de todas las ciudades griegas». ${ }^{54}$ Incluso las leyes de Solón de Atenas, que suele ser considerado el primero que contribuyó a desvincular la política de la religión, tienen restos de esa primigenia relación entre adivinación y legislación: el oráculo de Delfos le guió en su labor política y el adivino Epiménides le asistió en la redacción de sus leyes. ${ }^{55}$

$\mathrm{Si}$ estas reliquias de legisladores-adivinos se dan en el mundo de las metrópolis griegas, en la Magna Grecia se evidencia aún más esta antigua conexión en figuras de pensadores que, como Parménides, Zenón o el propio Pitágoras, también legislaron para sus conciudadanos. ${ }^{56}$ Una serie de hombres divinos de raigambre mántica cumplió funciones de legislación sacra en diversas ciudades del sur de Italia. Uno de ellos es Zaleuco, precursor de legisladores y, alternativamente, alumno de Pitágoras o compañero en sus viajes de aprendizaje a Egipto. Según la Política de Aristóteles, ${ }^{57}$ Zaleuco

49. Heródoto: (II, 164) y Isócrates: (Bus. 15-16). Hernández de la Fuente: 2013.

50. Cf. Froidefond: 1971.

51. Cf. Hernández de la Fuente: 2010, 110-114.

52. Plutarco: Lyc., 4.-5.

53. IsóCR.. Bus. 18-20.

54. Heródoto: i, 655 y Diodoro de Sicilia: vii, 12.

55. Plutarco: Sol., 12.

56. Dióg. Laercio. ix, 23. Sobre los legisladores pitagóricos cf. Porfirio: Vit. Pyth., 21, Jámblico: Vit. Pyth., 130.

57. Aristóteles: Pol., II, 12, 1274a, 22s. 
dio las leyes a los Locrios Epicefirios, y para Platón, que refleja una tradición extendida en el mundo griego, se trata de uno de los pueblos mejor legislados entre los griegos..$^{58}$ Otras figuras de este mundo de la legislación pitagórica, como Carondas de Catania, que habría legislado para su ciudad y para otras del ámbito de la Magna Grecia u Onomácrito que nació también entre los Locrios Epicefirios, también emprendieron viajes de iniciación legislativa a Creta o Egipto.

Pero, sin lugar a dudas, el ejemplo por excelencia del legislador de inspiración divina y mántica, y fundador de reglas y preceptos universales es el propio Pitágoras. No tenemos certeza del tiempo que dedicó Pitágoras a su periodo de aprendizaje, tanto religioso como legislativo, en Egipto, Creta y Oriente, así como del tiempo que transcurrió en Samos, poniendo a prueba lo que había aprendido en sus viajes con la fundación de su escuela en su isla natal, llamada el Semicírculo. La estancia en Creta debe quedar enmarcada, como se ha visto, en el periodo de aprendizaje religioso pero también político, marcado por las iniciaciones en la cueva del Ida y por el prestigio general de Creta y su constitución como lugar para aprender la «buena ley», más que como parte de su periplo por Grecia antes de establecerse en Crotona. También su especial relación con el Apolo de Delfos le pone en contacto con la tradición legislativa del mundo dorio, que encuentra sus orígenes en una serie de legisladores inspirados por la divinidad en Creta y Esparta: no es de extrañar entonces que, como se ha visto, la sociedad pitagórica mantenga unos fuertes lazos con los rituales sociales del mundo dorio, notablemente la ascesis física, la estricta iniciación por etapas, el papel sociopolítico de la música y las comidas en común (syssitiai).

Puede suponerse que, a lo largo de sus viajes «por los oráculos de Grecia» y por ciudades como Delos, Delfos, Esparta y Fliunte, Pitágoras hubiera puesto a prueba sus ideas religiosas o, quizá, sus nuevas leyes. ${ }^{59}$ En todo caso, podemos dar por cierto que su ensayo de comunidad mántica y política fracasó en las metrópolis griegas y que, en una secuencia histórica por lo demás bien atestiguada, decidió probar suerte en las colonias griegas de Italia. El traslado al occidente itálico se convirtió en una válvula de escape social y político en la Grecia arcaica, a un lugar donde poner a prueba las diversas formas de utopía política y religiosa que no podían prosperar en la Grecia metropolitana por la resistencia de las clases dominantes. Así cabe interpretar la noticia de que abandonó Samos por Crotona ante las condiciones políticas desfavorables que encontró para la realización de sus proyectos bajo la tiranía de Polícrates. ${ }^{60}$ Resulta paradójica la noticia que Jámblico refiere acerca de que Pitágoras se marchó de Samos precisamente al verse envuelto en los asuntos políticos «pues se veía obligado por sus conciudadanos a

58. Platón: Tim., 20a ss.

59. Dióg. Laercio: viII, 3, 13; Porfirio: Vit. Pyth., 17; Jámblico: Vit. Pyth., 25; Cicerón: Tusc. Qu., v, 3. 60. Porfirio: Vit. Pyth., 9. 
participar en las embajadas, y forzado a desempeñar cargos públicos», ${ }^{61}$ si se considera la vertiente política de sus enseñanzas en Crotona: sin duda es una referencia a la ley injusta que imperaba en su patria y a la imposibilidad de desarrollar allí un gobierno inspirado por sus preceptos espirituales.

El atractivo que pudo tener Crotona para Pitágoras se explica de varias maneras, empezando por su ya mencionada relación con el culto de Apolo. Desde el primer cuarto del siglo vi a. C. la ciudad dio buena muestra de su prosperidad y fama con el éxito de sus vencedores olímpicos. Pero también se convirtió en un centro de la ciencia griega destacando especialmente, como anticipara el oráculo fundacional de la ciudad, en el cultivo de la medicina. Las noticias de Heródoto confirman que los médicos de Crotona tenían una enorme reputación, ${ }^{62}$ hasta el punto de que el médico Demócedes de Crotona prestó sus servicios por todo el mundo griego acabando en la corte persa. Pero antes sirvió precisamente en la corte de Polícrates de Samos, el tirano del que había huido Pitágoras y que paradójicamente atrajo a muchos intelectuales de la Magna Grecia, como el poeta Íbico de Regio, entre otros. La relación de este flujo entre Samos y Crotona con el caso inverso de Pitágoras evidencia, sin duda, una disidencia más bien política y no intelectual. Por otra parte, no parece haber relación entre Demócedes y Pitágoras. ${ }^{63}$

La elección de Crotona como sede de la escuela pitagórica puede ponerse en relación con el florecimiento de la ciudad, que derrotó a su rival Síbaris en la guerra de 510 a. C., siendo comandadas sus tropas por un tal Milón, que muy bien podría ser el mismo atleta pitagórico en cuya casa murieron los miembros de la secta poco más tarde. El éxito político de la ciudad corrió parejas con el de los estudios filosóficos de la escuela pitagórica y con la medicina de Demócedes y Alcmeón de Crotona, a quien las fuentes tardías consideraron también pitagórico, ${ }^{64}$ aunque parece que fue contemporáneo del maestro. ${ }^{65} \mathrm{El}$ auge de la ciudad terminó con la sublevación de Cilón y sus partidarios, en torno a 508 a. C. El episodio que refieren las fuentes biográficas del filósofo parece regido por el típico esquema de la stasis en la política griega arcaica y clásica, ${ }^{66}$ en el que un grupo social amplio y posiblemente de tendencias populares, encabezado por un hombre de prestigio, intenta dar un golpe de mano para derrocar al grupo gobernante. En cuanto a la historia restante de la ciudad de Crotona, finalmente, hay que decir que, tras la guerra contra Síbaris y la revuelta antipitagórica, aún brilló por momentos, llegando a participar en la guerra contra los persas al enviar un barco a la batalla de Salamina (480 a. C.). ${ }^{67}$ Luego, la derrota de la ciudad ante dos poleis rivales,

61. JÁmblico: Vit. Pyth., 28.

62. Heródoto: I, 131.2.

63. Aunque hay un pitágorico con este nombre involucrado en la revuelta de CiLón cf. JámbLiCO; Vit. Pyth., 257-261.

64. Dióg. Laercio: viiı, 83; Jámblico: Vit. Pyth., 104, 267. Cf. ZhMud: 1997, 70.

65. Aristóteles: Met., A 5. Cf. Lloyd: 1991, 167.

66. TuCídides 3: 79-84; 6, 53 ss. LintotT: 1983, GeHRKE: 1985.

67. Heródoto: VIII 47. 
Lócride y Regio, supuso el inicio de su decadencia, hasta llegar a su conquista por Dionisio de Siracusa ya en el siglo IV a. C.

Pero en el caso de los pitagóricos y de su actividad pública en Crotona antes de la revuelta, aún se discute de qué signo era su orientación política, si era un grupo de tendencias democráticas o aristocráticas: en las fuentes encontramos afirmaciones contradictorias, pues a veces se presenta al grupo como adalid de las libertades y otras como grupo de tendencia elitista. ${ }^{68}$ El largo pasaje que contiene la anécdota de Fálaris y el discurso que dirige para refutar al tirano (Jámblico, Vit. Pyth., 218-221), por ejemplo, presentan a Pitágoras como un defensor de la libertad y de la virtud, así como la idea de que «liberó las ciudades itálicas» (Porfirio Vit. Pyth., 21, Jámblico Vit. Pyth., 214) de la tiranía y de las constituciones caóticas. Otros ejemplos a sensu contrario son el carácter elitista del grupo carismático, el hecho de que sus miembros eran seleccionados de entre las mejores familias de Crotona y otros testimonios que dicen que «otorgó leyes a los italiotas y fue muy celebrado por sus discípulos, los cuales eran trescientos y administraban los asuntos políticos de manera tan excelente que la constitución parecía casi una aristocracia». ${ }^{69}$

No cabe dudar de que los pitagóricos fueron objeto de sospechas de tiranía y calumnias de toda índole acerca de lo que pretendían lograr políticamente en la ciudad antes de que estallara la revuelta que puso fin a esta escuela. Un ejemplo de este estado de ánimo lo tenemos en la anécdota que refiere Jámblico (Vit. Pyth., 259) acerca del discurso que dirigió Ninón, un crotoniata contrario a Pitágoras y amigo del revoltoso Cilón, en el senado de la ciudad bajo el título Discurso sagrado, en un claro remedo irónico del texto sagrado que circulaba entre los órficos y, seguramente, también entre los pitagóricos. En el fragmento que recoge Jámblico se exponen las tesis de que los pitagóricos planeaban someter al pueblo, que

[...] comparaban a la gente común con ganado, pues eran partidarios de la oligarquía, combatían las judías porque son jefes de los sorteos y establece a los que participan en los asuntos públicos [es decir, mediante judías se votaba en las asambleas democráticas] e incitaban a la tiranía diciendo que es mejor ser un toro durante un día que un buey toda la vida. Elogiaban las constituciones de otros estados y exhortaban a practicar las que se habían decidido por uno mismo.

Diógenes Laercio da también testimonio de haber oído que los crotoniatas se rebelaron contra los pitagóricos «para precaverse de su tendencia a la tiranía» (viII, 39), en una acusación muy usual en la época para emprender una rebelión.

68. Riedweg: 2002 [2005], 17-18. JÁmblico: Vit. Pyth., 221, 255, etc.

69. Dióg. Laercio: vili, 3. Cf. también Jámblico: Vit.Pyth., 254. 
Que los pitagóricos tuvieron gran influencia en la política de la ciudad, lo prueba claramente el episodio de los embajadores de Síbaris..$^{70}$ Otros pasajes insisten en que los pitagóricos fueron políticos y legisladores pues, como dice Jámblico (Vit. Pyth., 129):

[...] hicieron guardar las leyes y dirigieron algunas ciudades de Italia, revelando y aconsejando las mejores medidas que pudieron concebir, pero absteniéndose de recibir un sueldo público... [los itálicos] quisieron que los asuntos constitucionales fueran administrados por aquellos. En esta época parece que las mejores constituciones se dieron en Italia y Sicilia.

Aunque no parece que ni Pitágoras mismo ni sus seguidores hubieran desempeñado cargos públicos, y ni mucho menos se puede hablar de ese grupo de trescientos miembros selectos como de una suerte de senado o asamblea pitagórica, sí cabe decir que el maestro y sus íntimos eran consultados como consejeros políticos de primer orden en asuntos públicos cuya importancia lo requiriese. ${ }^{71}$

No resulta difícil entender, así, el contexto en el que surgió la revuelta antipitagórica de Cilón. La tendencia aristocrática, al modo dorio, que puede rastrearse en los comportamientos grupales de los pitagóricos, bajo la guía inspiradora en Apolo y sus oráculos, dio pie a un grupo carismático que llegó a ejercer una fuerte presión e influencia en la política suritálica. ${ }^{72}$ Otras fuentes, como se ha visto, hablan de Pitágoras como de un adalid de la libertad que propicia la abolición de la tiranía: ${ }^{73}$ pero esto no es contradictorio con la caracterización del Pitagorismo como grupo elitista. La tiranía se relaciona con el apoyo de las clases populares: de hecho, el grupo de partidarios de Cilón tiene todos los rasgos de un grupo popular que se arremolina en torno a este hombre de fortuna y «tendencias tiránicas». La historia sobre el descontento del pueblo por el reparto de tierras efectuado por los pitagóricos, ${ }^{74}$ sumada a estas consideraciones, evidencia el tipo de revuelta antiaristocrática que se perfila y que se puede comparar con otros episodios semejantes en la historia política griega con trasfondo social y también religioso. ${ }^{75}$

Después de la victoria de los crotoniatas sobre Síbaris, en la que parece haber desempeñado cierto papel de liderazgo alguno de los pitagóricos, hubo una pugna política por el control del territorio conquistado. Los pitagóricos se habían significado en las complicadas relaciones de Crotona y Síbaris, como prueba la mediación política que refiere la leyenda de Pitágoras y los embajadores sibaritas. Pero en este momento, a la hora del reparto de las

70. JÁmblico: Vit. Pyth., 133, 177.

71. RiEDWEG: 2002 [2005], 60-61.

72. Para el carácter aristocrático de los pitagóricos, VON FrITZ: 1940, 72; Gorman: 1979 [1988], 189.

73. JÁmblico: Vit. Pyth., 220-221.

74. Cf. Jámblico: Vit. Pyth., 255.

75. Cf. JÁmblico: Vit. Pyth., 133. 
tierras adquiridas, los pitagóricos cobraron especial relieve en la esfera pública. Las fuentes, en este caso Jámblico, dependiendo de la versión del historiador helenístico Timeo ${ }^{76}$ apuntan como causa del conflicto la distribución desigual de las tierras: «Cuando se conquistó Síbaris, Pitágoras se ausentó y se administró la tierra conquistada sin repartirla en lotes según los deseos de la mayoría, el odio silenciado estalló y la multitud se puso en contra de los pitagóricos». ${ }^{77}$ Hay que suponer aquí que, tal vez desde la partida del maestro, los pitagóricos habían pasado de influir en la política mediante el prestigio carismático del líder a ostentar directamente magistraturas públicas y tomar decisiones políticas como el reparto de las tierras conquistadas.

En todo caso, la conjura, encabezada por Cilón y Ninón -y con el añadido personal de que el primero había sido rechazado en su intento de ser un pitagórico- acabó, como es sabido, con un ataque en el que perecieron casi todos los miembros del grupo.$^{78} \mathrm{El}$ final violento de la sociedad carismática es, por cierto, una nota definitoria de este tipo de grupo humano para la sociología de la religión weberiana. ${ }^{79}$ A esta stasis de Crotona y a la subsiguiente persecución de los pitagóricos en otras ciudades de la Magna Grecia siguió un periodo de guerras civiles en toda la zona que acabó con los gobiernos de distintas ciudades, hasta que la Magna Grecia fue pacificada por aqueos procedentes del Peloponeso. Así lo refiere el historiador Polibio de Megalópolis:

Por la época en que se produjo el incendio de las congregaciones pitagóricas en Italia y en la Magna Grecia, justo después, se produjeron disturbios muy notables en todos los regímenes políticos, como suele ser el caso cuando desaparece de forma tan inesperada la cúpula dirigente en cada estado; y sucedió que las ciudades griegas de aquella zona se llenaron de matanzas, revueltas civiles y de todo tipo de disturbios; en ese momento se enviaron legados de la mayor parte de las ciudades griegas para tratar de solucionar la situación. ${ }^{80}$

Otras fuentes históricas que hablan de este episodio lo enmarcan en las staseis políticas de la época, ${ }^{81}$ lo que evidencia el hecho de que acabara no solo con la expulsión de la hermandad de todas estas ciudades, sino también, como afirma Polibio, con la eliminación de sus gobiernos y el cambio de sus constituciones. Independientemente del papel político de los pitagóricos, que está más allá de toda duda, puede que en este período de disturbios los sublevados aprovecharan para extender su ataque a la aristocracia gobernante

76. VAN DER WAERDEN: 1979, 207 ss.

77. JÁmblico: Vit. Pyth., 255

78. Ya fuera en la casa de Milón, que fue incendiada según algunas versiones, ya en persecuciones por las calles y campos de Crotona. Cf. Jámblico: Vit. Pyth., 255 -259; Porfirio: Vit. Pyth., 54-57; Dióg. LAERCIO: VIII, 39.

79. Weber: 1978, 246 ss., 515 ss., Von Fritz: 1940, 72, Gorman: 1979 [1988], 189-192.

80. Polibio. II, 39.

81. Para el fenómeno en general, cf. GeHrKe: 1985. 
en diversas ciudades estado.$^{82}$ Con la mediación procedente de las metrópolis aqueas, y después de este periodo de revueltas, parece que se adoptaron constituciones renovadas y de origen aqueo en la mayor parte de la zona. ${ }^{83}$

La revuelta, cualquiera que fuese su motivación, acabó con la actividad pública de los antiguos pitagóricos y con su organización reglada, pues la hermandad nunca revivió como sistema de vida y como entidad políticamente relevante. En conclusión, y aunque la cuestión del final de la escuela pitagórica sigue sub iudice, la mayor parte de los indicios históricos y filológicos traídos aquí a colación apunta a que el líder de los pitagóricos, un grupo de tendencia elitista, se corresponde con el típico modelo del caudillo iluminado y carismático que, según las tesis weberianas, caracteriza al jefe de una secta político-religiosa. Si Pitágoras, como decía Cicerón en las líneas que encabezan este artículo, «quiso ser él mismo un adivino», no podemos dudar de que también consiguió ser un jefe político de una importante facción ciudadana. Las prerrogativas de la religión y la política, como en los tiempos homéricos, se volvían a conjugar en la figura del sabio de Samos.

\section{BiBLIOGRAFÍA}

Bremmer, J. N. (1992): «Symbols of Marginality from Early Pythagoreans to Late Antique Monks», Greece and Rome 39. 2, 205-214.

Burkert, W. (1962): Weisheit und Wissenschaft: Studien zu Pythagoras, Philolaos und Platon, Verlag Hans Carl, Nürnberg, [trad. ing. Lore and Science in Ancient Pythagoreanism. Cambridge, Mass., Harvard University Press, 1972].

Delatte, A. (1915): Études sur la littérature pythagoricienne, París, Champion.

- (1922): Essai sur la politique pythagorienne, París, Champion.

Detienne, M., (1967): Les Maîtres de vérité dans la Grèce antique, París, Maspero [trad. esp. México, Sexto piso, 2004].

DodDS, E. R. (1951): The Greeks and the Irrational, Berkeley [trad. esp. Madrid, Revista de Occidente, 1960, reimpr. Alianza 2010].

Eliade, M. (1956): Forgerons et alchimistes, París, Flammarion, [trad. esp. Madrid, Alianza, 1974].

Froidefond, C. (1971): Le mirage égyptien dans la littérature grecque d'Homére á Aristote. Université d'Aix en Provence.

GeHrKe, H.-J., (1985): Stasis. Untersuchungen zu den inneren Kriegen in den griechischen Staaten des 5. und 4. Jh. v. Chr. Múnich, C. H. Beck.

Gorman, P. (1979): Pythagoras. A Life, Londres, Routledge \& Kegan Paul [trad. esp. Barcelona, Crítica, 1988].

82. Cf. de nuevo Justino, xx 4; para la narración de toda la stasis, cf. JÁmblico, Vit. Pyth., 240-262.

83. Estrabón, viin 7 1. Confirma esta mediación Jámblico, Vit. Pyth., 263. 
Hernández de la Fuente, D. (2008): Oráculos griegos, Alianza: Madrid.

- (2010): «Mythische Vorbilder des sakralen Gesetzgebers bei Platon (Nomoi I-IV)», Zeitschrift für Religions- und Geistesgeschichte 62.2, 105-125.

- (2012): «El muslo de oro. Pitágoras como Prometeo», en F. Broncano y D. Hernández de la Fuente (eds.), De Prometeo a Frankenstein: autómatas, ciborgs y otras creaciones más que humanas, Ediciones Evohé, Madrid, 21-35.

- (2013): «Egipto como utopía: sobre el "Busiris" de Isócrates y su posible relación con el pensamiento político de Platón», Cuadernos de filología clásica: Estudios griegos e indoeuropeos, 23, 189-205.

HidAlgo DE la VegA, M. J. (2001): «Hombres divinos: de la dependencia religiosa a la autoridad política», Arys: Antigüedad: religiones y sociedades, 4, 211-230.

Kingsley, P., (1999): In the Dark Places of Wisdom, California, The Golden Sufi Center [trad. esp. Madrid, Atalanta 2010²].

LÉvy, I. (1927): La légende de Pythagore: de Grèce en Palestine, París, Campion.

Lintott, A. (1982): Violence, Civil Strife and Revolution in the Classical City. Londres, C. Helm.

Lloyd, G. E. R. (1991): Methods and Problems in Greek Science, Cambridge: Cambridge University Press.

Meuli, K. (1935). «Scythica», Hermes 70, 121-176.

Minar, E. L. (1943): Early Pythagorean politics in practice and theory. Baltimore: Waverley Press, Inc. [reimpr. Arno Press 1979].

Riedweg, C. (2002): Pythagoras: Leben, Lehre, Nachwirkung. Eine Einführung, München: C. H. Beck [trad. ing. Cornell University Press, 2005].

SChibli, H. S. (1990): Pherekydes of Syros, Oxford, Clarendon Press.

VAn der Waerden, B. L. (1979), Die Pythagoreer. Religiöse Bruderschaft und Schule der Wissenschaft, Artemis Verlag, Zúrich.

Von Fritz, K. (1940): Pythagorean Politics in. Southern Italy. Nueva York: Columbia University Press; Londres: Milford.

Weber, M. (1978): Economy and Society. An Outline of Interpretive Sociology. 2 vols. Ed. and trans. G. Roth, C. Wittich, et al., Berkeley, Los Angeles, Londres.

Zhmud, L. (1997): Wissenschaft, Philosophie und Religion im frühen Pythagoreismus. Berlín: Akademie. 